\section{Issues for future mental health legislation}

original papers

Throughout the 20th century, there has been a trend in mental health legislation to bolster the legal safeguards of patients' rights, and the ability of the nearest relative to discharge their next of kin was itself a novel feature of the 1983 Act. The tide appears to be turning. Recent legislation on supervised discharge orders has reduced the role of the nearest relative to that of a 'consultee whose views must be taken into account but with no power to prevent or discharge the order' (Department of Health, 1998). Future plans to remove this safeguard and replace it with a 'nominated person' with no powers of discharge should be supported by research to demonstrate its detrimental effects. This study does not support fears that a discharge by the nearest relative places patients in 'relative' danger.

\section{Acknowledgements}

We thank all the administrators of the Mental Health Act in the trust and the secretarial staff in the Department of
Psychological Medicine at King's College Hospital for help with finding notes.

\section{References}

ADAMS, S. J., PITRE, N. L. \& England and Wales, 1984-1996.

MYERS, D. H. (1997) Mental health CESZKOSWKI, R. (1997) Who applies to the Regional Review Boards and what are the outcomes? Canadian Journal of Psychiatry, 42, 70-76

DEPARTMENT OF HEALTH (1998) Mental Health Act Commission. Eighth Biennial Report 1998. London: HMSO

- (1999) H. M. Government's Green Paper on Reform of the Mental Health Act 1983: Proposals for Consultation. London: HMSO.

HOTOPF, M. WALL, S., BUCHANAN, A. et al (2000) Changing patterns in the use of the Mental Health Act 1983 in

British Journal of Psychiatry, 176 479-484. review tribunals: a follow-up of reviewed patients. British Journal of Psychiatry, 170, 253-256.

WALL, S., BUCHANAN, A., FAHY,T., et al (1999) A Systematic Review into the Use of the Mental Health Act 1983 London: HMSO

WILKINSON, P. \& SHARPE, M. (1993) What happens to patients discharged by the Mental Health ReviewTribunals? Psychiatric Bulletin, 17, 337-338.

*Philip Shaw Clinical ResearchWorker, Matthew Hotopf Clinical Senior Lecturer, Department of Psychological Medicine, Guy's, King's and StThomas' School of Medicine and the Institute of Psychiatry, London, Anthony Davies Consultant Psychiatrist, South London and Maudsley NHS Trust

\title{
Workload implications of the proposed new Mental Health Act - an audit
}

\author{
AIMS AND METHOD \\ To estimate specific time and \\ resource implications for profes- \\ sionals, if proposed changes to the \\ Mental Health Act 1983 (England \& \\ Wales) in the Government's white \\ paper were to be implemented \\ unchanged. An audit of time \\ spent on current procedures was \\ extrapolated.
}

\author{
RESULTS \\ The amount of time required to \\ comply with the Act will rise substan- \\ tially (by $27 \%$ overall). Social workers \\ and independent doctors will spend \\ $30 \%$ and $207 \%$ more time respec- \\ tively, complying with the Act, but \\ psychiatrists providing clinical care to \\ forensic patients should be largely \\ unaffected.
}

\begin{abstract}
CLINICAL IMPLICATIONS
If the Government presses ahead with its plans for mental health law reform as currently proposed, extra resources will be required to provide additional social work and independent medical time - or other services for patients will suffer.
\end{abstract}

Over the past few years, there has been a 'root-andbranch review' (Scoping Study Committee, 1999) of mental health legislation in England and Wales. In spite of the involvement of a large number of interested parties, many with strongly contrasting points of view, the process has resulted in a white paper (i.e. proposal for legislation) which embodies clear and consistent principles - albeit ones which, taken together, are substantially different from those of the present Mental Health Act and which do not seem to please everyone. A thorough critique of the proposals is beyond the scope of this paper, and can be found elsewhere (e.g. Royal College of Psychiatrists, 2001; Szmukler, 2001; Zigmond,
2001; Mind, 2001). However, in broad terms, the white paper represents a shift away from the Percy Commission's model of compulsory treatment being given only in the best interests of the individual patient and only as a last resort (Percy Commission, 1957) towards a model where protecting the public from the perceived dangerousness of patients assumes equal importance with providing care in the patient's best interests. The white paper, while carefully worded in an attempt to avoid conflict with the Human Rights Act 1998, would seem to permit a massive increase in the use of compulsory powers, by widening the criteria for detention, by effectively establishing community treatment orders, and 
by delegating the power to detain, not to psychiatrists (with their emphasis on the best interests of the individual patient) but to new quasi-judicial mental health tribunals (which may well develop a broader view of their responsibilities).

This paper makes the assumption that part 1 of the white paper will be enacted without any substantial alteration and that the use of compulsory powers will, at the very least, not be reduced. We have not considered the resource implications of part 2 of the white paper, relating to high risk patients and 'dangerous severe personality disorder'. The Mental Health Act 1983 included more bureaucratic checks and balances than its 1959 predecessor, and required a significant increase in resources. Because there are similar fears about the white paper (Royal College of Psychiatrists, 2001), we have tried to evaluate these concerns in a formal way, despite the lack of clarity for some of the details in the

\begin{tabular}{|c|c|c|c|c|}
\hline Events & $\begin{array}{l}\text { Statutory processes } \\
\text { (1983 Act) }\end{array}$ & Time & $\begin{array}{l}\text { Probable equivalent } \\
\text { under new Act }\end{array}$ & Time \\
\hline $\begin{array}{l}\text { Seen in prison by } \\
\text { consultant psychiatrist; } \\
\text { transfer to hospital } \\
\text { recommended }\end{array}$ & $\begin{array}{l}\text { Section } 38 \text { assessment } \\
\text { by section } 12 \text {-approved } \\
\text { doctor }\end{array}$ & 2 hours & $\begin{array}{l}\text { Report proposing remand for } \\
\text { assessment }\end{array}$ & 2 hours \\
\hline $\begin{array}{l}\text { Convicted of } \mathrm{ABH} \text { and } \\
\text { criminal damage; court } \\
\text { makes interim hospital } \\
\text { order (section 38) }\end{array}$ & $\begin{array}{l}\text { Section } 38 \text { assessment } \\
\text { by second doctor }\end{array}$ & 2 hours & & \\
\hline $\begin{array}{l}\text { Transferred to medium- } \\
\text { secure hospital }\end{array}$ & & & $\begin{array}{l}\text { Second doctor later concurs } \\
\text { that care and treatment } \\
\text { order may be appropriate }\end{array}$ & 1 hour \\
\hline $\begin{array}{l}\text { Period of assessment in } \\
\text { hospital }\end{array}$ & $\begin{array}{l}\text { RMO and a colleague } \\
\text { both make reports } \\
\text { recommending a hospi- } \\
\text { tal order (section 37) }\end{array}$ & 2 hours each & $\begin{array}{l}\text { Clinical supervisor makes a } \\
\text { report recommending a care } \\
\text { and treatment order }\end{array}$ & 3 hours \\
\hline $\begin{array}{l}\text { Patient refuses consent } \\
\text { to long-term anti- } \\
\text { psychotic medication }\end{array}$ & $\begin{array}{l}\text { Second opinion doctor } \\
\text { (SOAD) reviews patient } \\
\text { and completes form } 39\end{array}$ & $2 \frac{1}{4}$ hours & $\begin{array}{l}\text { Independent doctor } \\
\text { reviews patient and } \\
\text { completes consent- } \\
\text { to-treatment form }\end{array}$ & $2 \frac{1}{4}$ hours \\
\hline $\begin{array}{l}\text { Hospital reviews RMO's } \\
\text { authority to detain } \\
\text { patient }\end{array}$ & $\begin{array}{l}\text { RMO and social worker } \\
\text { write reports for and } \\
\text { attend managers' } \\
\text { meeting }\end{array}$ & $\begin{array}{l}1 \frac{1}{2} \text { hours for } \\
\mathrm{RMO}, 8 \text { hours for } \\
\text { social worker }\end{array}$ & $\begin{array}{l}\text { No equivalent - } \\
\text { managers' meetings } \\
\text { abolished }\end{array}$ & \\
\hline Hospital order renewed & $\begin{array}{l}\text { RMO completes section } \\
37 \text { renewal form }\end{array}$ & 3 hours & $\begin{array}{l}\text { Clinical supervisor applies } \\
\text { to mental health tribunal for } \\
\text { extension of care and treat- } \\
\text { ment order, after receiving } \\
\text { reports from team } \\
\text { Independent doctor reviews } \\
\text { patient and reports to tribunal }\end{array}$ & $\begin{array}{l}2 \text { hours } \\
\text { (plus } 1 \text { hour } \\
\text { by colleagues) } \\
2 \frac{1}{4} \text { hours }\end{array}$ \\
\hline $\begin{array}{l}\text { Patient appeals against, } \\
\text { or requests review of, } \\
\text { detention }\end{array}$ & $\begin{array}{l}\text { RMO and social worker } \\
\text { write reports for and } \\
\text { attend mental health } \\
\text { review tribunal }\end{array}$ & $\begin{array}{l}2 \frac{1}{4} \text { hours for } \\
\mathrm{RMO}, 8 \text { hours for } \\
\text { social worker }\end{array}$ & $\begin{array}{l}\text { Clinical supervisor writes report } \\
\text { for and attends mental health } \\
\text { tribunal, after receiving reports } \\
\text { from team }\end{array}$ & $\begin{array}{l}2 \frac{1}{2} \text { hours } \\
\text { (plus } 8 \text { hours } \\
\text { by social worker) }\end{array}$ \\
\hline Totals & $\begin{array}{l}\text { RMO } \\
\text { Other psychiatrists } \\
\text { Social workers } \\
\text { SOAD }\end{array}$ & $\begin{array}{l}8 \frac{3}{4} \text { hours } \\
6 \text { hours } \\
16 \text { hours } \\
2 \frac{1}{4} \text { hours }\end{array}$ & $\begin{array}{l}\text { Clinical supervisor } \\
\text { Other psychiatrists } \\
\text { Social workers } \\
\text { Independent doctors }\end{array}$ & $\begin{array}{l}7 \frac{1}{2} \text { hours } \\
4 \text { hours } \\
8 \text { hours } \\
4 \frac{1}{2} \text { hours }\end{array}$ \\
\hline
\end{tabular}

ABH: actual bodily harm; RMO: responsible medical officer 
proposals. We are unaware of the publication of any other structured attempt to do this.

original

papers

\section{The study}

This audit set out to calculate the amount of time professionals had spent complying with the requirements of the current Mental Health Act (England \& Wales) in a given setting and during a given period. It was then estimated how much time would have been required, had a new Act based on the white paper been in force. For practical reasons, and because a forensic psychiatric unit concentrates on detained patients, the Oxford Clinic was chosen for the study. This is a 30-bed, purpose-built, medium-secure forensic psychiatric unit with a catchment area (Oxfordshire and Berkshire) of approximately 1.5 million people. All patients in the unit are detained under the Mental Health Act, and the usual length of stay is $18-24$ months. This is typical for medium-secure units, as compared with an average length of stay of nearly 8 years for the three English high-security hospitals. All 54 patients admitted to the unit in the 18 months prior to May 2001 were identified, around two-thirds of whom were still in-patients. The full medical notes for all these patients were obtained and scrutinised by Sean Whyte, anonymously recording every 'statutory process'. This was administrative work, carried out by a professional, which related directly to detention under the Act, over and above work which would have been done as a matter of course during the clinical care of the patient. Detention ('section') papers, photocopies, letters and clear descriptions in notes were all accepted as evidence of statutory processes.

Separately, the average times required for each of the statutory processes were estimated after consultation with a selected group of colleagues from the two main professional disciplines relevant to the Act (psychiatrists and social workers). Between them, the chosen colleagues had experience of the different sections and parts of the Act, and of the different roles which could be played (e.g. responsible medical officer (RMO), second opinion approved doctor
(SOAD) etc.). The cost of each process was estimated using the hourly rates at the mid-point of the salary scales for each of the professionals concerned or the relevant fees, where paid.

Finally, both authors jointly considered the most probable way that each of the patients in the audit would have been dealt with, had a new Act based on the white paper been in force; the figures were then recalculated on this basis. Box 1 illustrates how these calculations were made in the case of one individual patient.

\section{Findings}

The main results of the audit are summarised in Table 1. The key finding is that the audit predicts a substantial rise ( $27 \%$ overall) in the amount of time professionals will have to spend to comply with the requirements of a new Act, but that this rise will only be significant for social workers and for independent doctors, working on behalf of the mental health tribunal (MHT).

We predict that social workers or, in some cases, their equivalent under a new Act, involved in the area included in the study will spend an extra 129 hours a year (a 30\% increase in time required) complying with the requirements of a new Act. This is principally because they will need to contribute to the full care plans and reports demanded by more frequent MHTs, although this will be offset somewhat by the abolition of managers' meetings.

Even more significant is the prediction that the time required by independent doctors (similar to SOADs) who will be employed by the new MHTs will be tripled. They will have to spend a considerable time assessing patients and writing reports in advance of each MHT meeting. This is an entirely new function, distinct from the 'medical member' of the current mental health review tribunals, who does not write a formal report and is to be separately replaced by a third MHT member, and distinct also from the right of the patient to employ their own independent psychiatrist.

Table 1. Difference in time taken to comply with new Act

\begin{tabular}{|c|c|c|c|c|}
\hline Professional group & $\begin{array}{l}\text { Average time taken } \\
\text { complying with } 1983 \\
\text { Act per year (hours) } \\
\text { (cost of that time, f) }\end{array}$ & $\begin{array}{l}\text { Estimated average time } \\
\text { to comply with new } \\
\text { Act per year (hours) } \\
\text { (cost of that time, } \mathrm{f} \text { ) }\end{array}$ & $\begin{array}{l}\text { Increase in hours } \\
\text { required (\%) }\end{array}$ & $\begin{array}{l}\text { Significance of } \\
\text { increase } \\
\text { in time required* }\end{array}$ \\
\hline RMO or clinical supervisor & $158(5015)$ & $181(5744)$ & $23(15)$ & No significant rise \\
\hline Other psychiatrists & $241(6221)$ & $232(6042)$ & $-9(4)$ & No significant rise \\
\hline Social workers & 423 (4306) & $552(5615)$ & $129(30)$ & $P<0.005$ \\
\hline SOAD or independent doctor & $42(1164)$ & $130(3576)$ & $87(207)$ & $P<0.001$ \\
\hline Total & $865(16707)$ & $1094(20976)$ & $230(27)$ & \\
\hline
\end{tabular}

*Using Wilcoxon matched-pairs signed-ranks test

RMO: responsible medical officer; SOAD=second opinion approved doctor 


\section{Comment}

There are many limitations to this study, not least the biased nature of the in-patient forensic psychiatric sample and the necessarily subjective nature of our estimates of the times required to comply with a new Act. Our estimates make a number of assumptions which may well turn out to be incorrect. These include assuming that the white paper will be enacted unchanged, that working practices will not alter other than as required by the Act and that the frequency of use of compulsory powers of detention will not change.

Notwithstanding these limitations, however, our central findings are likely to hold true, that social workers and independent doctors will be required to spend substantially more time complying with a new Act, whereas psychiatrists responsible for the clinical care of patients will not be significantly affected. This is particularly true for professionals working with patients from medium-secure units. We believe that these findings are also likely to apply to the many patients in other forensic psychiatric settings.

Our findings do not apply directly to general adult psychiatric services, where compulsory powers are used less frequently and different parts of the Act are employed. However, in a similar way, where care and treatment orders are used, social workers and independent doctors are still likely to need a lot more time than they do at present.

The implication of these findings for policymakers, if they are even partly true, is that the implementation of a new Act on the lines described in the white paper will require extra resources, both financial (to pay for the additional social work and independent medical time) and human. Even without these additional pressures, there are already worrying shortages of SOADs and independent doctors available to the mental health review tribunal. Unless this resource issue is tackled before the new legislation is enacted, patient clinical care is likely to be adversely affected.

\section{Acknowledgements}

We thank Lyn Taylor, Kathy Smith and the staff of the Littlemore Medical Records Department who assisted with locating notes, and our psychiatric and social work colleagues who helped us estimate times.

\section{Declaration of interest}

None.

\section{References}

MIND POLICY AND PARLIAMENTARY UNIT (2001) Mind and the Mental Health Act: 1-5. London: MIND.

PERCY COMMISSION (1957) Report of the Royal Commission on the Law Relating to Mental IIIness and Mental Deficiency (Cmnd 169). London: HMSO.

ROYAL COLLEGE OFPSYCHIATRISTS

(2001) White Paper on the Reform of the Mental Health Act 1983. Response from the College's Mental Health Law Sub-Committee. London: Royal College of Psychiatrists.
SCOPING STUDY COMMITTEE (1999) Review of Mental Health Act 1983. Draft outline proposals by Scoping Study Committee (Richardson Committee). London: Scoping Study Committee.

SZMUKLER, G. (2001) A new menta health (and public protection) act. BMJ, $322,2-3$.

ZIGMOND, A. S. (2001) Reform of the Mental Health Act 1983: the Green Paper. Psychiatric Bulletin, 25, 126-128.
*Séan Whyte Specialist Registrar, West London Mental Health NHS Trust, Gloucester House, 194 Hammersmith Road, LondonW6 8BS, Clive Meux Consultant Forensic Psychiatrist, The Oxford Clinic, Littlemore Mental Health Centre, Oxford OX4 4XN

\section{SIAN NERYS WESTON}

\section{Comparison of the assessment by doctors and nurses of deliberate self-harm}

\author{
AIMS AND METHOD \\ To compare the assessment by \\ community psychiatric nurses and \\ junior psychiatric doctors of \\ individuals following deliberate self- \\ harm (DSH) and, in particular, to elicit \\ differences in referral practices and \\ perceptions of mental illness. The \\ health professionals involved \\ completed questionnaires after \\ carrying out DSH assessment.
}

\author{
RESULTS \\ There was a significant difference in \\ referral patterns between doctors \\ and nurses after DSH assessment. \\ Doctors were significantly more \\ likely to refer individuals for psy- \\ chiatric follow-up which involved \\ direct contact with other doctors \\ (51 of $72(71 \%$ ) compared with 60 of \\ $175(34 \%))$. Doctors were also \\ significantly more likely than nurses
}

\author{
to perceive individuals as having a \\ mental illness (57 of $72(79 \%)$ \\ compared with 86 of $175(49 \%))$. \\ CLINICAL IMPLICATIONS \\ Further research is warranted \\ to establish the precise reasons \\ for these differences, and to \\ determine whether the widespread \\ introduction of nurse-led services \\ is an effective and efficient use of \\ resources.
}

The number of admissions to hospitals in England and

Wales following deliberate self-harm (DSH) has remained in excess of 100000 each year for two decades (Royal

College of Psychiatrists, 1994). Deliberate self-harm is one 